\title{
Kebijakan Pengendalian HIV/AIDS di Denpasar
}

\author{
Control Policy of HIV/AIDS in Denpasar
}

Tri Rini Puji Lestari

Pusat Pengkajian dan Pengolahan Data Informasi Sekretariat Jenderal DPR RI

\begin{abstract}
Abstrak
Secara nasional, Indonesia telah mengantisipasi epidemi HIVIAIDS, tetapi jumlah kasus HIVIAIDS di Provinsi Bali dari tahun ke tahun memperlihatkan peningkatan yang semakin mengkhawatirkan. Penelitian ini bertujuan untuk mengetahui perkembangan jumlah kasus dan kebijakan penanggulangan HIVIAIDS di Denpasar. Penelitian ini menggunakan metode kualitatif yang dilakukan di Denpasar pada tanggal 11-17 September 2011. Sampel penelitian ini menggunakan informan terpilih yaitu kepala bappeda, pejabat Dinas Kesehatan Kabupaten Denpasar, direktur rumah sakit, puskesmas, ketua komisi penanggulangan AIDS di kabupaten/kota dan pemerhati HIVIAIDS termasuk ODHA. Penelitian menemukan jumlah kasus HIVIAIDS di Kota Denpasar yang tertinggi dan penularan terbesarnya melalui hubungan seks. Namun, dukungan pemerintah daerah dalam upaya pencegahan dan penanggulangan HIVIAIDS terlihat belum maksimal. Padahal kebijakan penanggulangan HIVIAIDS sangat ditentukan oleh cara pandang pemerintah terhadap penyakit HIVIAIDS. Untuk itu, perlu peningkatan pemahaman tentang HIVIAIDS serta pencegahan dan penanganan semua pihak terkait sehingga penanggulangan HIVIAIDS dapat lebih efektif, efisien, dan tepat sasaran.
\end{abstract}

Kata kunci: HIVIAIDS, kebijakan, pengendalian

\footnotetext{
Abstract

Nationally, Indonesia anticipated HIVIAIDS epidemic, but the number of cases of HIVIAIDS in Bali province from year to year showed an increase in the increasingly alarming. This study aimed to determine the number of cases and the development of policies on HIV / AIDS in Denpasar. This research was conducted using qualitative methods in Denpasar on 11-17 September 2011. The study sample was selected using the informant is head of planning, Denpasar District health officers, the director of the hospital, health center, chairman of the commission on AIDS in the district/city and observer of HIV / AIDS, including people living with HIV. The study found the number of cases of HIV / AIDS in the city of Denpasar is the highest and greatest transmission through sexual intercourse. However, the support of local go-
}

vernments in efforts to prevent and control HIVIAIDS looks not maximized. In fact the policy of HIVIAIDS is largely determined by the government perspective on HIV / AIDS. To that end, should be an increased understanding of HIVIAIDS as well as prevention and treatment of all parties concerned. So that HIVI AIDS can be more effective, efficient, and targeted.

Keywords: HIVIAIDS, policy, control

\section{Pendahuluan}

Setiap tahun, penyebaran HIV/AIDS memperlihatkan kecenderungan yang cepat dan meluas. Kasus HIV/AIDS pertama ditemukan di Provinsi Bali, pada tahun 1987, penderita adalah warga Belanda yang dirawat di Rumah Sakit Umum Pusat Sanglah Denpasar. Pada periode 1987 - 1999, kasus HIV masih tergolong rendah, sebagai akibat sosialisasi konseling dan pemeriksaan sukarela belum dilakukan secara optimal. Pada tahun 2000, jumlah kasus mulai memperlihatkan kecenderungan yang meningkat. Sebagian besar penduduk yang kehilangan kekebalan daya tahan tubuh tersebut $(4.314 ; 79,88 \%)$ adalah kelompok usia produktif yang meliputi usia 20 - 29 tahun (1.932; $44,78 \%$ ) dan usia $30-39$ tahun (1.514; 35,10\%). Di Bali, penderita HIV yang tercatat berjumlah 1.163 kasus meliputi laki-laki 652 kasus dan perempuan 511 kasus. Kelompok usia 30 - 39 tahun mencapai 1.514 kasus yang meliputi AIDS 851 kasus yang terdiri atas laki-laki 705 kasus dan perempuan 146 kasus, serta HIV 663 kasus meliputi lakilaki 417 kasus dan perempuan 246 kasus. $^{1}$

Jumlah kasus HIV/AIDS yang meningkat setiap tahun,

Alamat Korespondensi: Tri Rini Puji Lestari, Pusat Pengkajian dan Pengolahan Data Informasi Setjen DPR RI, Gedung Nusantara I Lt. 2, Jl. Gatot Subroto Jakarta Pusat 10270, Hp.081382312169,e-mail: tririni74@yahoo.com 
mengantarkan Indonesia menjadi salah satu negara dengan epidemi HIV/AIDS tercepat di Asia Tenggara. Pada tahun 1987 - 2007, Komisi Penanggulangan AIDS Nasional hanya mencatat 5 dan 44 kasus penderita AIDS, tetapi sejak 2007, jumlah dan penyebaran kasus melonjak menjadi 2.947 kasus. Pada Juni 2009, jumlah tersebut meningkat delapan kali lipat menjadi 17.699 kasus dengan kematian 3.586 kasus. Sejak tahun 2004, Indonesia berada dalam tahap bahaya karena enam dari 33 provinsi yang meliputi Jakarta, Papua, Bali, Jawa Barat, Jawa Timur, dan Riau, berada dalam tahapan epidemi HIV/AIDS. Selama tiga tahun terakhir, tiga provinsi yang lain meliputi Kalimantan Barat, Sumatera Utara, dan Sulawesi Utara, memperlihatkan tren epidemi HIV. ${ }^{1}$ Di tingkat daerah, tidak kalah memprihatinkan, pada tahun 2014, diprediksi sekitar 501.400 kasus HIV/AIDS. Meskipun di Papua, prevalansi HIV/AIDS masih yang tertinggi, tetapi jumlah kasus HIV/AIDS tidak lagi yang terbanyak. ${ }^{2}$ Upaya penanggulangan menjadi target MDGs, HIV/AIDS telah menyebar di 33 provinsi dan 300 kabupaten/kota di Indonesia.

Di Indonesia, Strategi Nasional 2007 - 2010 merupakan upaya antisipasi yang dijabarkan dalam Strategi Penanggulangan HIV/AIDS. Upaya tersebut meliputi peningkatan cakupan pencegahan; perawatan, dukungan dan pengobatan, serta pengurangan dampak negatif epidemi. Upaya tersebut dilakukan dengan meningkatkan akses program mitigasi sosial; menguatkan kemitraan, sistem kesehatan dan sistem masyarakat; meningkatkan koordinasi dan mobilisasi dana; mengembangkan intervensi struktural; serta menerapkan perencanaan, prioritas dan implementasi program berbasis data. Strategi penanggulangan mencakup upaya pencegahan, pengobatan, mitigasi dampak dan pengoptimalan lingkungan kondusif. masyarakat berada pada posisi yang sangat penting. Pada era otonomi daerah, dana APBN tidak mungkin lagi diandalkan sehingga Pemda, LSM, tokoh agama dan adat harus berperan aktif mendidik masyarakat untuk memahami dampak HIV/AIDS. ${ }^{3}$ Penelitian ini bertujuan untuk mengetahui perkembangan jumlah kasus dan kebijakan penanggulangan HIV/ AIDS di Denpasar.

\section{Metode}

Penelitian dengan metode kualitatif ini mengumpulkan data melalui observasi dan wawancara mendalam, serta data sekunder dokumen dan profil kesehatan. ${ }^{4,5} \mathrm{Wa}-$ wancara mendalam dilakukan pada informan terpilih di kabupaten/kota meliputi kepala Bappeda, dinas kesehatan, direktur rumah sakit, puskesmas, serta ketua Komisi Penanggulangan AIDS, ODHA dan pemerhati HIV/AIDS. Analisis dilakukan secara deskriptif dengan memperhatikan poin kunci reduksi data dan intepretasi. Reduksi data dilakukan dengan memilah-milah data menjadi potongan-potongan yang lebih teratur dengan menyusun kategori, dan merangkum menjadi pola dan susunan yang se- derhana. Interpretasi dilakukan untuk mendapatkan makna dan pemahaman terhadap ucapan dan tindakan para informan dengan menampilkan konsep dan teori berdasar generalis yang menjelaskan temuan di lapangan. ${ }^{6}$

\section{Hasil \\ Perkembangan Kasus HIV/AIDS}

Menurut informan dari dinas kesehatan pada tahun 1999 dan 2000, jumlah kasus HIV/AIDS di provinsi Bali adalah 59 dan 108 kasus. Pada akhir Oktober 2008, jumlah kumulatif kasus HIV/AIDS mencapai 2.413 kasus yang meliputi 1.107 kasus AIDS dan 1.306 kasus HIV. Kasus tertinggi ditemukan di Kota Denpasar diikuti Bandung dan Buleleng. Sampai Juli 2011, tercatat 4.631 kasus, seki$\operatorname{tar} 78,94 \%$ kasus menular melalui hubungan seks, terbanyak melalui hubungan heteroseks $(73,35 \%)$ dan melalui jarum suntik pengguna narkoba $(16,71 \%)$ (Tabel 1).

Kecamatan yang termasuk berisiko tinggi penularan HIV/AIDS meliputi Denpasar Selatan terutama wilayah Sanur, Denpasar Timur Pasiran dan Padang Galak, serta Denpasar Utara wilayah Carik dan Lumintang. Lokasi wanita penjaja seks (WPS) yang terbesar di Kota Denpasar adalah wilayah Sanur meliputi Danau Tempe Barat dan Timur, Danau Poso, Bungalow Sanur, wilayah Padang Galak dan Pasiran serta Carik dan Lumintang. Sekitar 4.000 WPS ditemukan di delapan lokasi langsung dan tidak langsung, tidak termasuk yang bertransaksi tertutup. Pada 1987 2008, jumlah penderita AIDS mencapai 413 kasus dengan jumlah kematian 105 kasus, sedangkan dan penderita HIV (+) berjumlah 804 orang. Jumlah seluruh penderita HIV/AIDS adalah 1.217 orang, terbanyak adalah kelompok usia 20 - 29 tahun. Kasus tertinggi dilaporkan pada Juli 2011, dengan jumlah penderita HIV/AIDS adalah 2.051 kasus $(44,29 \%)$, dengan jumlah kasus HIV dan AIDS adalah 1.140 dan 1.090. Pada Juli 2011, prevalensi penderita dilaporkan $44,29 \%$, merupakan yang tertinggi dengan kasus HIV dan AIDS berjumlah 1.140 dan 1.090.

\section{Kebijakan Penanggulangan HIV/AIDS}

Sejak tahun 2006, Pemda Provinsi Bali memberlakukan

Tabel 1. Data Situasi Kasus HIV/AIDS di Kota Denpasar dari Tahun 2002-2009

\begin{tabular}{llllllll}
\hline \multirow{2}{*}{ Tahun } & \multicolumn{2}{c}{ AIDS } & \multicolumn{2}{c}{ HIV } & \multicolumn{2}{c}{ Jumlah } & \\
\cline { 2 - 6 } & Kasus & Mati & Kasus & Mati & Kasus & Mati nn & \\
\hline 2002 & 11 & & 95 & 0 & 106 & 3 & 106 \\
2003 & 27 & 4 & 175 & 0 & 202 & 4 & 202 \\
2004 & 64 & 17 & 262 & 0 & 326 & 17 & 326 \\
2005 & 140 & 33 & 426 & 0 & 566 & 33 & 566 \\
2006 & 183 & 42 & 475 & 0 & 658 & 42 & 658 \\
2007 & 279 & 63 & 612 & 0 & 891 & 63 & 891 \\
2008 & 413 & 105 & 804 & 0 & 1217 & 105 & 1217 \\
2009 & 481 & 129 & 916 & 0 & 1526 & 129 & 1526 \\
2010 & 780 & 162 & 922 & 1 & 1702 & 163 & 1702 \\
\hline
\end{tabular}


Tabel 2. Hasil kegiatan CST di RSUD Wangayah Bali

\begin{tabular}{lllllll}
\hline \multirow{2}{*}{ Uraian } & \multicolumn{2}{c}{2007} & \multicolumn{2}{c}{ 2008 } & \multicolumn{2}{c}{2009} \\
\cline { 2 - 7 } & $\mathbf{n}$ & $\%$ & $\mathbf{n}$ & $\%$ & $\mathbf{n}$ & $\%$ \\
\hline Kunjungan ke VCT & 699 & & 622 & & 833 & \\
Klien yang ditest & 237 & 33,9 & 334 & 53,69 & 427 & 51,26 \\
Hasil test klien HIV (+) & 73 & 30,8 & 91 & 27,25 & 144 & 33,72 \\
ODHA yang dirujuk ke ARV & 21 & 28,77 & 27 & 29,67 & 35 & 24,31 \\
Pasien HIV dengan co infeksi TB & 27 & 36,99 & 31 & 34,07 & 43 & 29,86 \\
\hline
\end{tabular}

perda No. 3 tahun 2006 tentang Penanggulangan HIV/ AIDS. Perda tersebut mengatur upaya penanggulangan HIV/AIDS yang meliputi promosi, pencegahan, konseling dan tes sukarela rahasia, pengobatan, serta perawatan dan dukungan. Pemerintah provinsi menyediakan sarana prasarana yang terjangkau, meliputi pendukung pengobatan, pengadaan obat anti retroviral, obat anti infeksi oportunistik dan obat IMS. Gubernur dan bupati/walikota berkoordinasi dan mengawasi upaya penanggulangan yang meliputi aspek pengaturan dan pelaksanaan. Pemerintah menciptakan suasana yang mendukung melalui "Gerakan Penanggulangan HIV dan AIDS" terutama pada kelompok risiko tinggi. Kegiatan komunikasi, informasi, dan edukasi juga dilakukan untuk mendorong perilaku hidup sehat pada anak sekolah, remaja, dan masyarakat umum. Materi termasuk pengguna kondom pada setiap hubungan seks berisiko dan upaya melepaskan ketergantungan pada kalangan pengguna narkoba suntik secara berkala. Menurut informan dari Dinas Kesehatan pada tahun 2009, dilakukan pemeriksaan darah sero dan sentinel yang ditargetkan 850 sampel, namun yang terealisasi hanya 747 sampel $(87,88 \%)$ (Tabel 2$)$.

Menurut informan dari rumah sakit, sejak Juli 2004 upaya penemuan, pengobatan dan pemantauan penderita di Provinsi Bali, NTT, dan NTB dilakukan di RSP Sanglah, yang merupakan pelayanan unggulan yang bersifat sosial. Pada periode 2004 - 2010, jumlah pasien yang melakukan konseling adalah 5.802 kasus dengan pasien reaktif adalah 1.435 kasus (25\%). Rata-rata penderita yang melakukan tes adalah 117 kasus dengan kasus reaktif sekitar 25\%. Penderita AIDS dengan pengobatan ARV berjumlah 783 kasus dan sekitar 25 pasien menggunakan pengobatan lini 2. Operasi caesar dilakukan terhadap 70 kasus dengan bayi/anak yg menderita HIV dan pengobatan ARV pada 28 kasus. Setiap tahun, jumlah pasien yang dirawat adalah 315 kasus dan sekitar 40\% merupakan pasien baru. Menurut informan dari rumah sakit sejak 2004, pasien yang dirawat berjumlah 2.250 kasus dengan jumlah kematian 400 kasus $(17,8 \%)$ dan pasien TB-HIV berjumlah 60 kasus. Faktor risiko yang terbanyak adalah heteroseksual, umur 15 - 49 tahun, dan jenis kelamin lakilaki. Pada tahun 2010 kinik methadon melaporkan 78 pasien yang mendapat terapi ARV10 kasus dan yang mendapat pengobatan TB adalah satu kasus.

Pada tahun 2009, menurut informan di puskesmas II Denpasar Selatan telah dilakukan sosialisasi PMTCT dengan sasaran 240 ibu hamil, pengambilan darah sero survei dilakukan pada kelompok risiko tinggi dan $747 \mathrm{ibu}$ hamil serta pemberian pengobatan presumptif berkala terhadap 1.750 WPS. Kendala yang dihadapi upaya penanggulangan HIV/AIDS antara lain adalah stigma dan diskriminasi, penolakan, pengingkaran, dan ketidakpedulian kelompok marginal dan ODHA. Selain itu, menurut informan migrasi dan mobilitas penduduk tergolong tinggi, respons berbagai kalangan terhadap epidemi HIV/AIDS bervariasi dan pembiayaan yang diberikan terlalu kecil dibandingkan dengan kebutuhan.

Kemitraan dengan LSM yang secara khusus menangani HIV/AIDS masih belum ada, pengamatan penyakit melalui sistem informasi kesehatan sangat terbatas. Cakupan populasi kunci rendah karena keterbatasan informasi dan berbagai hambatan akses. Informan dari pemerhati HIV/AIDS mengatakan bahwa mobilisasi WPS tergolong tinggi, tetapi keterlibatan kelompok masyarakat tergolong rendah. Ada kesenjangan yang tinggi antara pengetahuan tentang IMS, HIV/AIDS, dan penggunaan kondom. Cakupan pelayanan VCT masih rendah, sementara informan dari ODHA berpendapat kalau konselor sangat terbatas dengan mobilitas yang sangat tinggi. ${ }^{8}$

\section{Pembahasan}

Jumlah kasus HIV/AIDS di Kota Denpasar merupakan yang tertinggi. Denpasar termasuk wilayah yang berisiko tinggi penularan HIV/AIDS, karena banyak tempat hiburan malam yang rawan transaksi penjaja seks komersial atau lokalisasi dan buruh migran. Hal tersebut didukung pula oleh laporan KPA bahwa penularan terbanyak melalui hubungan seks $(78,94 \%)$.

Menurut Achmadi ${ }^{9}$, strategi pengendalian penyakit menular pada dasarnya menghilangkan sumber penyakit dengan cara menemukan dan mencari kasus secara proaktif, kemudian melakukan pengobatan hingga sembuh. Intervensi faktor risiko misalnya lingkungan dan intervensi terhadap perilaku. Selain itu, menurut Suesen dalam Soelistijani, ${ }^{10}$ pencegahan penularan HIV melalui hubungan seksual memerlukan penyuluhan yang intensif 
dan ditujukan untuk mengubah perilaku seksual masyarakat sehingga mengurangi kemungkinan penularan HIV sehingga diharapkan pengetahuan yang diterima WPS nantinya mampu merubah sikap dan perilaku untuk mencegah HIV/AIDS. Terkait kebijakan pengendalian HIV/ AIDS, pemda Provinsi Bali telah memperlihatkan komitmen terhadap penanggulangan HIV/AIDS, terbukti dengan dikeluarkan perda tentang penanggulangan HIV/ AIDS, tetapi beberapa kabupaten/kota belum membuat dan melaksanakan Perda tersebut.

Kebijakan penanggulangan HIV/AIDS sangat ditentukan oleh cara pandang pemerintah terhadap penyakit HIV/AIDS. ${ }^{1}$ Namun, pemerintah daerah kabupaten/ Kota Denpasar belum berpihak pada upaya penanggulangan HIV/AIDS, Rencana Strategis Dinas Kesehatan Kota Denpasar tahun 2010 - 2015, belum memasukkan rencana dana Program Pencegahan dan Penanggulangan Penyakit Menuar HIV/AIDS. Dana upaya penanggulangan HIV/AIDS baru berasal dari Provinsi Bali.

Semangat kebijakan lebih terfokus pada penanganan kasus, penegasan tugas, kewajiban dan tanggung jawab serta sanksi bagi lembaga kesehatan. Di Kota Denpasar, penanggung jawab utama pelayanan HIV/AIDS serta mekanisme koordinasi partisipasi warga, masih rendah. Padahal, penanggulangan dan penanganan kasus HIV/ AIDS telah menjadi prioritas kinerja pemerintah di semua tingkatan. Klinik IMS dan VCT diharapkan berkontribusi pada penemuan kasus HIV/AIDS dini, edukasi HIV dan AIDS, penurunan kasus HIV/AIDS, serta peningkatan angka kesembuhan kasus HIV/AIDS. Namun, berbagai klinik tersebut baru dibentuk, berbagai kegiatan belum dievaluasi. Perlu upaya keras mengubah citra bahwa HIV/AIDS merupakan penyakit "kutukan" untuk mendorong keterbukaan ODHA dan mendekonstruksi resistensi cara bepikir masyarakat. ${ }^{4}$

Upaya penanggulangan HIV/AIDS harus memperhatikan nilai agama, budaya, norma kemasyarakatan, menghormati harkat dan martabat manusia, serta keadilan dan kesetaraan gender. Upaya penanggulangan harus diintegrasikan ke dalam program pembangunan di tingkat nasional, provinsi dan kabupaten/kota. Upaya penanggulangan HIV/AIDS yang dilakukan meliputi peningkatan perilaku hidup sehat, pencegahan penyakit, perawatan, dukungan dan pengobatan penanggulangan HIV/AIDS dilakukan oleh masyarakat sipil dan pemerintah, berdasarkan prinsip kemitraan. Dukungan kepada ODHA dan mereka yang terdampak HIV/AIDS bertujuan untuk memberdayakan dan mempertahankan kehidupan sosial ekonomi yang layak dan produktif. KPA Kota Denpasar dapat mengoptimalkan sumber daya untuk peningkatan klinik IMS, klinik VCT dan CST, serta kesadaran dan kepedulian berbagai pihak dalam upaya penanggulangan HIV dan AIDS.

\section{Kesimpulan}

Provinsi Bali menunjukkan peningkatan kasus HIV/ AIDS, sebagian besar penularan terjadi melalui hubungan seks. Masyarakat semakin mudah mengakses layanan VCT sehingga semakin banyak yang melakukan pemeriksaan HIV. Keterlibatan berbagai komponen masyarakat meliputi pemerintah dan swasta. Belum semua Kabupaten/Kota Provinsi Bali yang memiliki Perda tentang pencegahan dan penanggulangan HIV/AIDS. Berakibat pada dukungan dana dan kerjasama multisektor. Penanggulangan HIV/AIDS di Denpasar sebagian besar merupakan program nasional dan belum ada program khusus pemerintah daerah. Evaluasi kegiatan program belum dilakukan secara berkala.

\section{Saran}

Perlu peningkatan pemahaman tentang HIV/AIDS serta pencegahan dan penanganan semua pihak terkait. Perencanaan dan pengawasan diperlukan agar penanggulangan HIV/AIDS dapat lebih efektif, efisien, dan tepat sasaran. Perlu penelitian lebih lanjut untuk mengetahui tingkat efektivitas klinik-klinik IMS dan VCT dalam penanganan HIV/AIDS di Denpasar Provinsi Bali.

\section{Daftar Pustaka}

1. Anonimous. Epidemi HIV/AIDS di Indonesia dalam bahaya. Harian Kompas tanggal 17 April 2004.

2. Widodo TR. Raperda penanggulangan HIV/AIDS setengah hati. Harian Bernas tanggal 6 Maret 2010.

3. Komisi Penanggulangan Aids. Strategi nasional HIV/AIDS 2007-2010 [online]. 2010 [diakses 27 Mei 2011]. Diunduh dalam: http://www. undp.or.id/programme/pro-poor/ The \% 20 National $\% 20 \mathrm{HIV} \% 20$ \& $\%$ 20AIDS \%20 Strategy \% 202007-2010\%20\% 28 Indonesia29.pdf.

4. Sumantri Arif. Metodologi penelitian kesehatan. Jakarta: Kencana Prenada Media Group; 2011.

5. Suryana Asep. Tahap-tahapan penelitian kualitatif. Jakarta: Fakultas Ilmu Pendidikan Universitas Pendidikan Indonesia; 2007.

6. Daymone C, Holloway I. Metode-metode riset kualitatif. Astuti SI, penyunting. Yogyakarta: Bentang; 2008.

7. Anonimous. Tiga kabupaten di Bali belum punya perda HIV [Diakses tanggal 13 Juli 2011]. Diunduh dalam: http://wap.vivanews.com/news/$\mathrm{read} / 229879$-tiga-kabupaten-di-bali-belum-punya-perda-hiv.

8. Komisi Penanggulangan AIDS Nasional. Strategi dan rencana aksi nasional penanggulangan HIV dan aids 2010-2014. Jakarta: KPAN; 2010.

9. Fahmi AU. Manajemen penyakit berbasis wilayah. Jakarta: Penerbit Buku Kompas; 2005.

10. Ariani DP, Hargono . Analisis hubungan antara pengetahuan, sikap dengan tindakan berdasarkan indikator surveilans perilaku HIV/AIDS pada wanita pekerja seks (studi penelitian di klinik IMS Puskesmas Putat Jaya Surabaya). Jurnal Berkala Epidemiologi [online]. 2012: 1: 1 [diakses tanggal 3 Desember 2013]. Diunduh dalam: http://www.journal. unair.ac.id/filerPDF/001_putu_001.doc. 